\title{
DAYLIGHT PERFORMANCE AND ENERGY CONSUMPTION IN A SIMPLE ROOM OF RESIDENTIAL BUILDING IN DHAKA CITY, BANGLADESH
}

\author{
Sajal Chowdhury*, Md. Rabiul Alam, and Shajib Paul \\ Department of Architecture, CUET, Chittagong, Bangladesh \\ *Corresponding author (sajal c@yahoo.com)
}

\begin{abstract}
Daylight is the main contributor to save the energy consumption in the residential building because it is the most valuable natural resources available to architects and engineers to develop the visual quality of interior spaces. It is accredited that a significant reduction in artificial lighting and subsequent primary energy consumption can be achieved by maximizing the use of natural lighting (daylight). Therefore, strategies are needed for more daylight inclusion in the interiors of the residential building where electricity demand is very high. The main objectives of this study are to identify parameters of day lighting that can help to save energy consumption and to develop the daylight performances in a simple room in residential building in Dhaka city, Bangladesh. This study also helps the Bangladesh National Building Code (BNBC) to identify the minimum daylight parameters for a typical residential building which is constructed by local materials.
\end{abstract}

\section{Keywords: Daylight, Energy Consumption, Residential Building, Artificial Lighting}

\section{INTRODUCTION}

In Bangladesh, the demand of residential building is increasing high for it's over growing population. Therefore, a tremendous problem of energy crisis is seen to be created and subsequently demand of extra energy is increased for residential building to fulfill the demand of over population. In order to minimize this problem numerous researches have been carried in the last few decades. This paper presents the results of simulations of daylight strategies in one simple pattern of room with six different window configurations. The window configurations taken into considerations are; i) A vertical window without shading; ii) A vertical window with shading; iii) A horizontal window without shading; iv) A horizontal window with shading; v) A corner window with shading and vi) A corner window without shading. No various shading device and louvers are included in this analysis. Only one simple type of shading device is used for this study. Simulations are performed using Radiance Lighting Simulation System (Ward Larson \& Shakespeare, 1998). All daylight components and variables which are important for proper day lighting and strategies of energy consumption are considered in proper way during simulation. Thermal comfort is also considered in this study.

\section{CLIMATE OF DHAKA CITY}

Dhaka city has mainly three different seasons. These are:

1. The hot dry season (March-May)

2. The hot humid season (June- November)

3. The cool dry season (December- February)

April is considered as hottest month and is considered average temperature is available as $30.3-34.8 \mathrm{deg} \mathrm{c}$

January is considered as coldest month and is considered average temperature is available as $9-15.2 \mathrm{deg} \mathrm{c}$

Table: 1 Sky condition with respect to cloud covers for year (Joarder, AR, 2007.)

\begin{tabular}{|c|c|c|c|c|c|}
\hline \multirow{2}{*}{$\begin{array}{l}\text { Type } \\
\text { of Sky }\end{array}$} & \multirow[b]{2}{*}{$\begin{array}{l}\text { Hot Dry } \\
\text { Pre- } \\
\text { Monson } \\
\text { March- } \\
\text { May }\end{array}$} & \multicolumn{2}{|c|}{ Warm Humid } & \multirow{2}{*}{$\begin{array}{l}\text { Cool } \\
\text { Dry } \\
\text { Dec- } \\
\text { Feb }\end{array}$} & \multirow{2}{*}{$\begin{array}{l}\text { Total } \\
\text { Day }\end{array}$} \\
\hline & & $\begin{array}{l}\text { Monso } \\
\text { on } \\
\text { June- } \\
\text { Sept }\end{array}$ & $\begin{array}{l}\text { Post- } \\
\text { Monsoon } \\
\text { Oct-Nov }\end{array}$ & & \\
\hline $\begin{array}{l}\text { Clear } \\
\text { Sky }\end{array}$ & 62 & 38 & 39 & 77 & 215 \\
\hline $\begin{array}{l}\text { Overca } \\
\text { st Sky }\end{array}$ & 30 & 84 & 22 & 14 & 150 \\
\hline $\begin{array}{l}\text { Total } \\
\text { Days }\end{array}$ & 92 & 122 & 61 & 90 & 365 \\
\hline
\end{tabular}


Sky condition with respect to cloud cover for year is shown in Table 1. It is seen that April is the hottest month with average temperature of $32 \operatorname{deg} \mathrm{C}$ and January is the coldest month with temperature of $15 \operatorname{deg} \mathrm{C}$.

\section{PRESENT SENARION OF ENERGY CONSUMPTION}

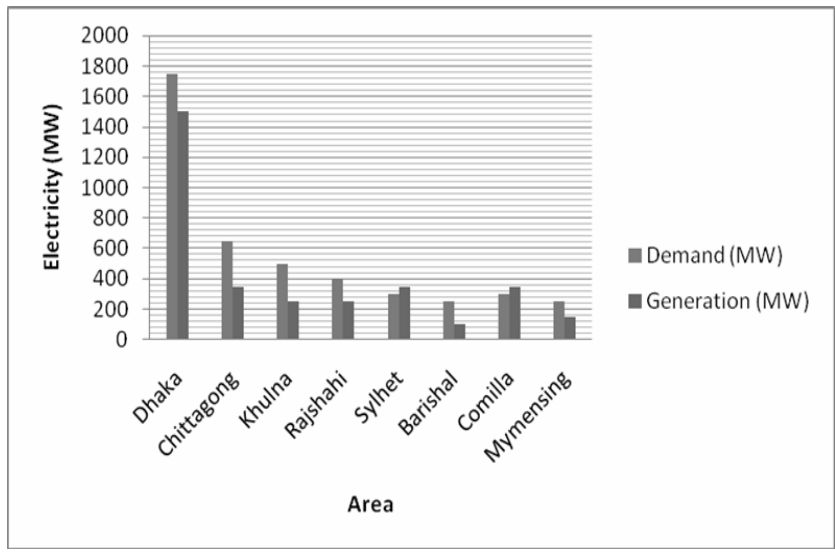

Fig. 1 Maximum demand and generation in area wise peak hour (Dhaka power development board, Bangladesh, 2010)

Fig. 1 represents electricity demand and generation scenario in peak hour of eight main cities in Bangladesh. From Fig. 1 it can be seen that there is a big difference of energy demand and generation in Dhaka city with others.

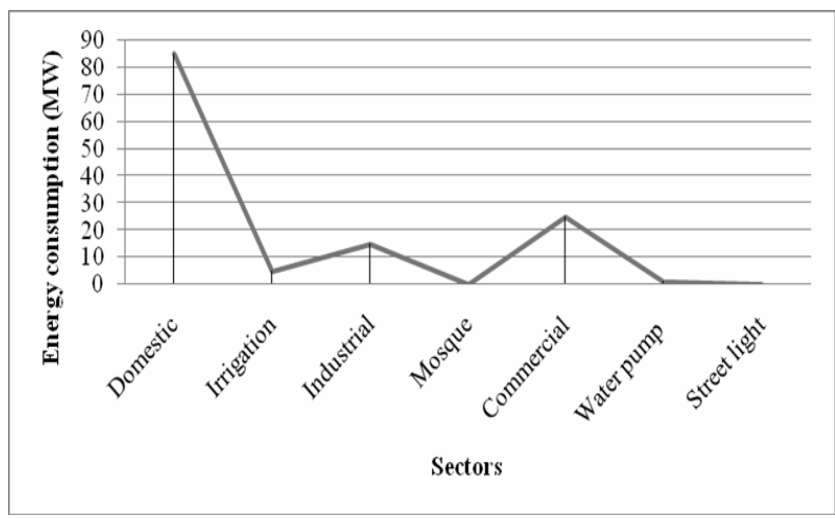

Fig. 2 Electric energy consumption pattern in various sectors of Dhaka city (Power distribution board Dhaka, Bangladesh, 2010)

Fig. 2 represents electric consumption pattern in various sectors of Dhaka city. In Fig. 2 it is seen that in domestic sector the highest energy consumption is happened at Dhaka city, Bangladesh.

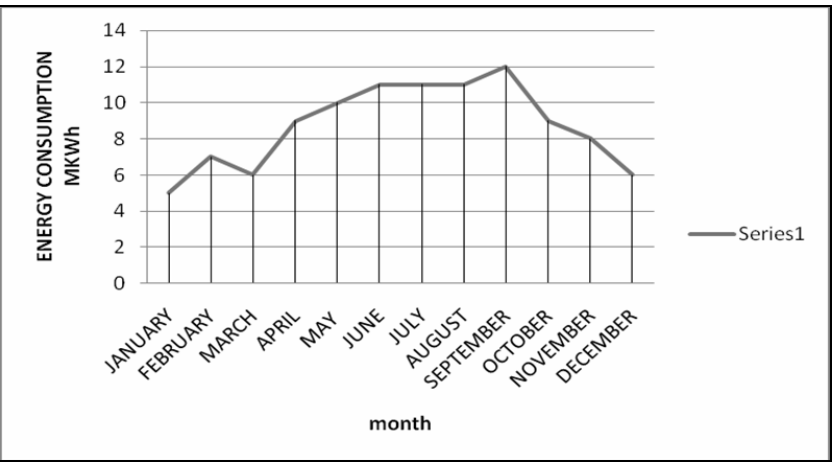

Fig. 3 Electric energy consumption pattern in various months in Dhaka city (Power distribution board Dhaka, Bangladesh, 2010)

In Fig. 3 it is shown that from the month of April to September energy consumption rate is high at Dhaka, Bangladesh.

\section{COMPUTER SIMULATION STRATEGICS}

The entire computer simulation was carried out for daylight conditions in six patterns of windows under overcast and sunny sky conditions for one orientation at three different months and times of the day in a year. The simple rooms having similar floor area, floor to ceiling height identical glazing (area and glass combination), glazing height and identical wall, floor and ceiling reflectance were taken into consideration in this study.

Climate-based daylight modeling (CBDM) was carried out using computer simulation techniques. The computational engine used to predict the daylight performances was Radiance and Eco-Tect lighting simulation. The Radiance \& Eco-Tect system is the most severely validate day lighting simulation program currently available. Flow chart of this system is shown in Fig.4

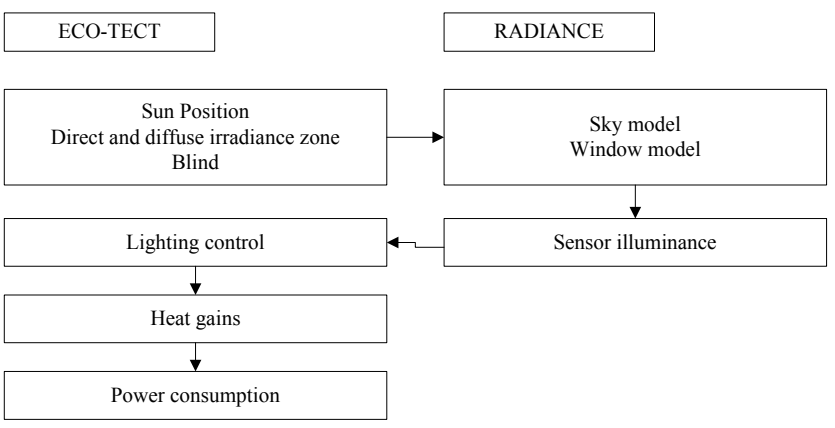

Fig. 4 Approach to combined thermal \& lighting simulation 


\section{MODELING DATA AND PROCEDURE}

An apartment type building shown in Fig. 5 is selected for analysis in the present study. This building consists of 3 flats of different sizes in each floor and elongates in east west directions. A master bed which is situated at the first floor in the south east corner of the building is taken into consideration in this study. The wall of the whole building is considered to be constructed by local brick and the color of the inner and outer sides of the wall is considered as white. Room height is considered as $3.00 \mathrm{~m}$ and walls thickness is considered as $125 \mathrm{~mm}$. Ceiling is considered to be constructed by RCC with a thickness of $125 \mathrm{~mm}$.

Combined thermal and lighting phenomenon was used in the analysis to critically examine the performance of six cases shown in Table 2.

Table: 2 Case studies for simulation studies

\begin{tabular}{|c|c|c|}
\hline \multicolumn{2}{|c|}{ Case study } & \multirow[t]{3}{*}{ Remarks } \\
\hline Type 1 & $\begin{array}{l}\text { - A vertical window } \\
\text { without shading }\end{array}$ & \\
\hline Type 2 & $\begin{array}{l}\text { - A vertical window } \\
\text { with shading }\end{array}$ & \\
\hline Type 3 & $\begin{array}{lr}-\quad \text { A } & \text { horizontal } \\
\text { window } & \text { without } \\
\text { shading } & \\
\end{array}$ & \multirow{4}{*}{$\begin{array}{l}\text { No obstruction in } \\
\text { front of the } \\
\text { window. } \\
\text { Inner surface is } \\
\text { white. } \\
\text { Desirable room } \\
\text { temperature } 26 \text { - } \\
28 \text { deg Celsius }\end{array}$} \\
\hline Type 4 & $\begin{array}{lr}-\quad \text { A } & \text { horizontal } \\
\text { window } & \text { with } \\
\text { shading } & \\
\end{array}$ & \\
\hline Type 5 & $\begin{array}{l}\text { - A corner window } \\
\text { with shading }\end{array}$ & \\
\hline Type 6 & $\begin{array}{l}\text { - A corner window } \\
\text { without shading }\end{array}$ & \\
\hline
\end{tabular}

Isometric representation of six pattern of window in north direction is shown in Figs. 6(a) and (b)

The entire studies (six pattern residential windows types) are performed in a simple room for the benefit of comparison of daylight condition and energy consumption. Room size is considered as $3.5 \mathrm{~m}$ by $3.5 \mathrm{~m}$ (depth) and ceiling height $3.00 \mathrm{~m}$ and windows area are considered as $3.750 \mathrm{sqm}$, (total wall openings) respectively. Room is considered to be constructed by cleared glass construction (average $\mathrm{u}$ value for cleared glass construction 5.100 $\mathrm{w} / \mathrm{m} 2 \mathrm{k})$. In all cases all windows are located $0.76 \mathrm{~m}$ above the floor level and are made with $25.4 \mathrm{~mm}$ aluminum frame. Impact of exterior surface has not been considered on the interior surface. Model of the 3 storied residential building taken into consideration in this analysis is shown in Fig. 5.

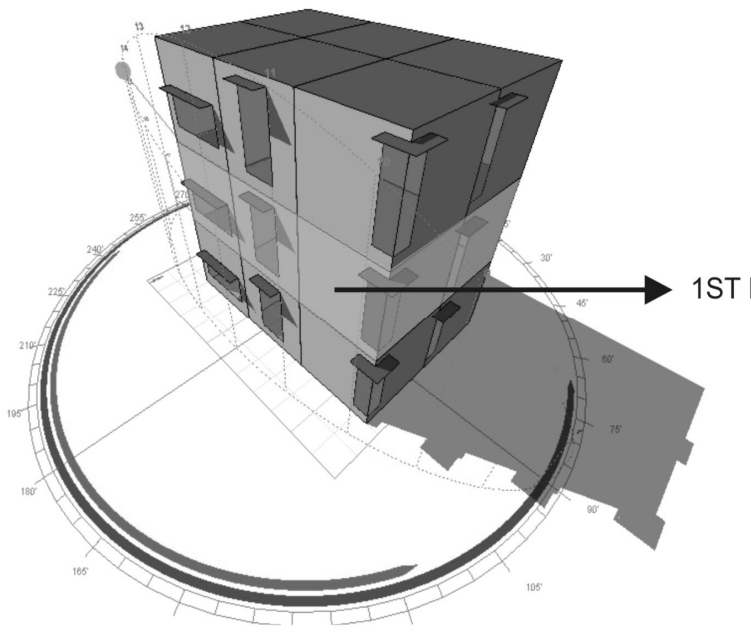

Fig. 5 Model of the 3 storied residential building with shadow effect (gray color indicate the study zone which is situated at the south east corner)

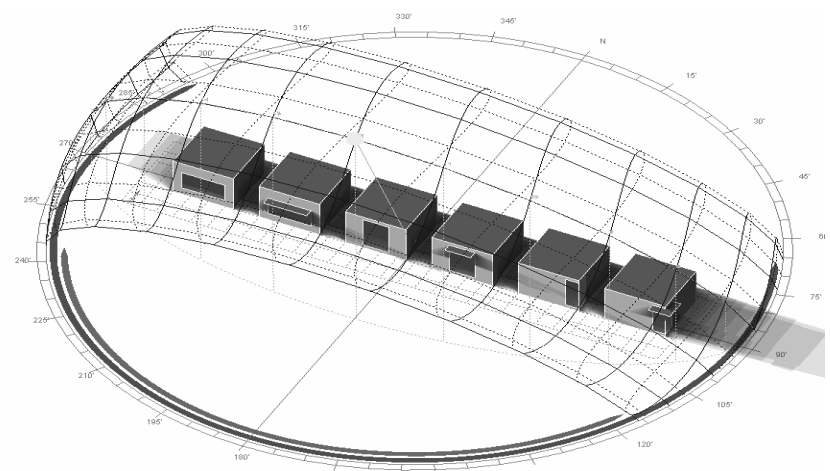

Fig. 6(a) Isometric representation of six pattern of window in north direction

\begin{tabular}{|l|l|}
\hline & $\begin{array}{l}\text { Figure: A } \\
- \text { A vertical window without } \\
\text { shading } \\
-\mathrm{A} \text { vertical window with } \\
\text { shading }\end{array}$ \\
\hline & $\begin{array}{l}\text { Figure: B } \\
-\mathrm{A} \text { horizontal window } \\
\text { without shading } \\
- \text { A horizontal window with } \\
\text { shading }\end{array}$ \\
\hline
\end{tabular}




\begin{tabular}{|l|l|}
\hline & $\begin{array}{l}\text { Figure: } \mathrm{C} \\
-\mathrm{A} \text { corner window with } \\
\text { shading } \\
- \text { A corner window without } \\
\text { shading }\end{array}$ \\
\hline
\end{tabular}

Fig. 6(b) Isometric representations of six pattern of window

Inner surface properties of wall, window, roof and floor, glazing, shading device and the $U$ value of the construction materials are shown in Table 3.

Table: 3 Properties of inner surface, glazing and shading device and the U Value of the construction materials

\begin{tabular}{|c|c|}
\hline Wall & $\begin{array}{l}\text { Material: } 110 \mathrm{~mm} \text { brick with } 10 \mathrm{~mm} \text { plaster in } \\
\text { both sides. } \\
\text { Surface Area: } 38.250 \mathrm{~m} 2 \\
\text { U Value: } 2.620 \\
\text { Solar Absorption: } 0.418 \\
\text { Thermal Decrement: } 0.7\end{array}$ \\
\hline Window & $\begin{array}{l}\text { Material: Single pane of glass with aluminum } \\
\text { frame (no thermal break). } \\
\text { Surface Area: } 3.750 \mathrm{~m} 2 \\
\text { U Value: } 6.000 \\
\text { Solar Absorption: } 0.94 \\
\text { Thermal Decrement: } 1.74 \text { (refractive index of } \\
\text { glass) }\end{array}$ \\
\hline Roof & $\begin{array}{l}\text { Material: Concrete Roof Asphalt } \\
\text { Surface Area: } 12.250 \mathrm{~m} 2 \\
\text { U Value: } 0.896 \\
\text { Solar Absorption: } 0.9 \\
\text { Thermal Decrement: } 0.58\end{array}$ \\
\hline Floor & $\begin{array}{l}\text { Material: } 100 \mathrm{~mm} \text { thick concrete slab on } \\
\text { ground. } \\
\text { Surface Area: } 12.250 \mathrm{~m} 2 \\
\text { U Value: } 0.880 \\
\text { Solar Absorption: } 0.467 \\
\text { Thermal Decrement: } 0.3\end{array}$ \\
\hline $\begin{array}{l}\text { Shading } \\
\text { device }\end{array}$ & $\begin{array}{l}\text { Material: Concrete Roof with plaster } \\
\text { Surface Area: } 12.250 \mathrm{~m} 2 \\
\text { U Value: } 0.896 \\
\text { Solar Absorption: } 0.9 \\
\text { Thermal Decrement: } 0.58\end{array}$ \\
\hline
\end{tabular}

The simulations were performed for the location of Dhaka (latitude $25.4^{\circ} \mathrm{N}$; longitude $23.38^{\circ} \mathrm{E}$ ) under the following sky conditions of CIE overcast sky and CIE sunny sky for seven months on selected (sunny) days. Simulated data and time taken into consideration are given in Table 4.

Table: 4 Simulation months, hours and time schedule

\begin{tabular}{|l|l|l|l|}
\hline $\begin{array}{l}\text { Simulation } \\
\text { month }\end{array}$ & April & July & October \\
\hline Simulation date & 1 st & 1 st & 1 st \\
\hline Time & $\begin{array}{l}12.00 \\
\text { pm }\end{array}$ & $\begin{array}{l}12 . \\
00 \\
\text { pm }\end{array}$ & $12.00 \mathrm{pm}$ \\
\hline
\end{tabular}

Modeling procedure has been generated from Eco tect and Radiance simulation software for the months of April, July and October under the consideration of local climate.

\section{RESULT AND DISCUSSIONS}

According to the modeling considerations the daylight factor, room temperatures and artificial lighting level were calculated with the help of Eco-Tect and Radiance software (Building performance software) for all types of windows. From the simulation result it is seen that horizontal window without the shading device has achieved the highest range of daylight factors and corner window with shade has achieved the lowest range of daylight factors. However, horizontal window without the shading device has not shown good thermal comfort level. The penetration of daylight in the room could be the reasons of raise temperature and created discomfort into the indoor environment.
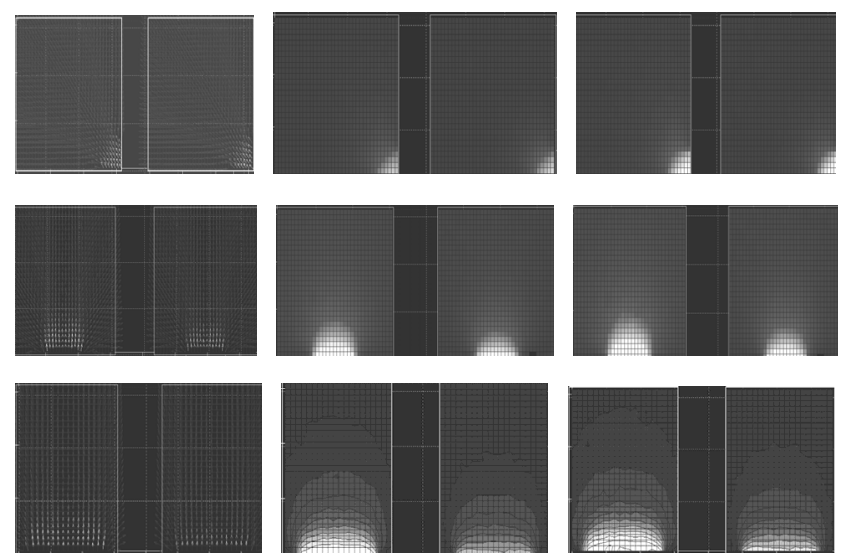

Fig. 8 Day lighting level of (from up to bottom); a) corner 
window; b) vertical window; c) horizontal window according to the months of April, July and October

The penetration range of daylight in various months according to described modeling considerations is shown in Fig. 8. From this figure it is seen that horizontal window without shading device has achieved the highest penetration range (the last corner image)

The comparison of daylight level of six types of windows is shown Fig. 9 and Table 5.

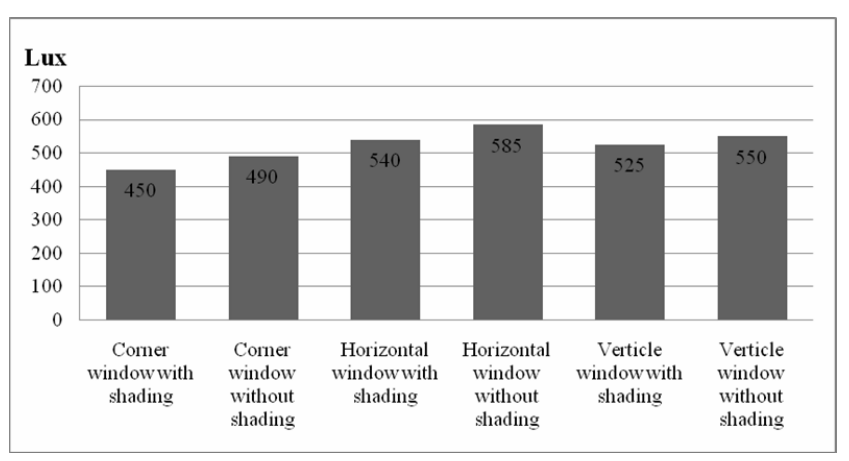

Fig. 9 Comparison of daylight level of various type of windows pattern according to the simulation

It is seen that when day light is high in the inner side of the room, discomfort level is created and temperature becomes high. The change of temperature for six analysis cases is shown in Fig. 10. It is seen that the use of shading device, indoor temperature reduces significantly.

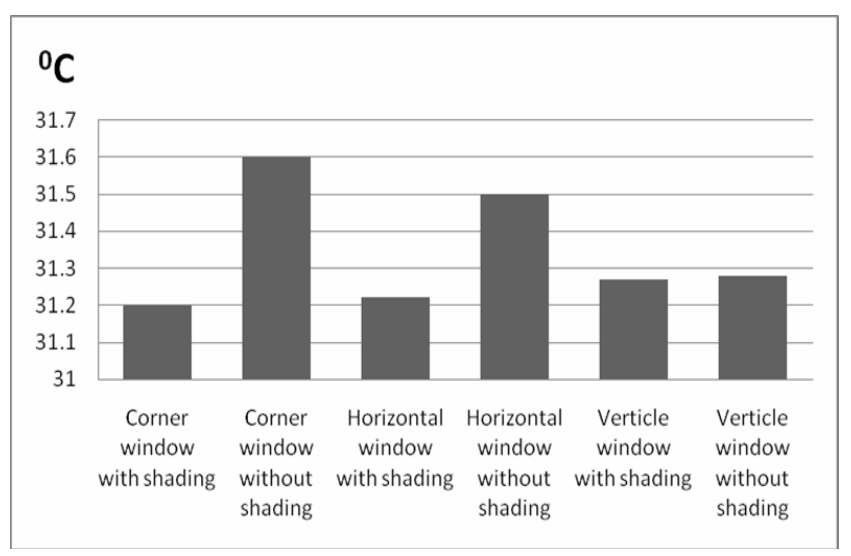

Fig. 10 Comparison of thermal comfort level of various type of windows pattern
Thermal comfort level of various type of windows pattern is shown in Fig. 10. In this figure it is seen that room temperature without shading windows either horizontal or vertical is almost same and high for all patterns of windows. Among them corner window without shading is found to be the highest temperature. Horizontal pattern of window with or without shading shows good room temperature.

Table: 5 Daylight level of three simulation months

\begin{tabular}{|c|c|c|c|}
\hline Window type & April & July & October \\
\hline corner window with shade & 450.63 & 487.63 & 420.23 \\
\hline $\begin{array}{l}\text { corner window without } \\
\text { shade }\end{array}$ & 493.5 & 508.17 & 447.18 \\
\hline $\begin{array}{l}\text { horizontal window with } \\
\text { shade }\end{array}$ & 539.57 & 555.63 & 508.16 \\
\hline $\begin{array}{l}\text { horizontal window without } \\
\text { shade }\end{array}$ & 587.63 & 598.76 & 534.16 \\
\hline vertical window with shade & 545.68 & 589.62 & 522.68 \\
\hline $\begin{array}{l}\text { vertical window without } \\
\text { shade }\end{array}$ & 588.37 & 602.24 & 558.62 \\
\hline
\end{tabular}

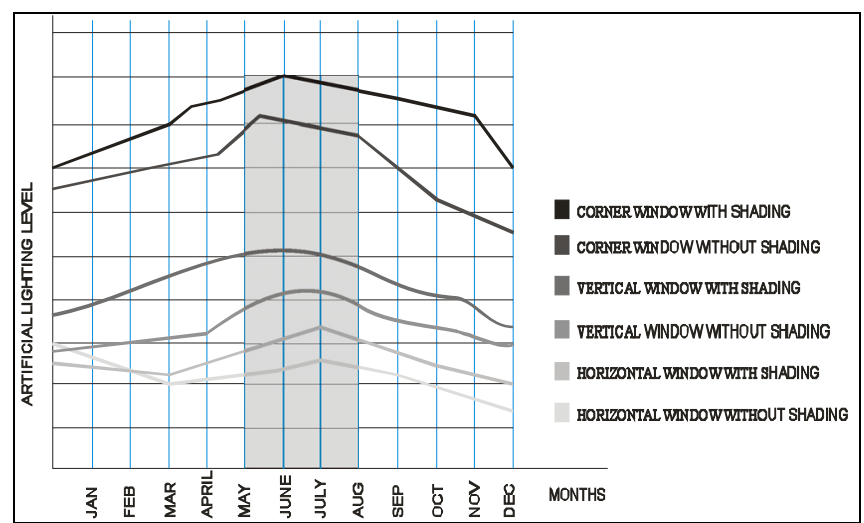

Fig. 11 Comparison of artificial lighting level of various type of windows pattern

The artificial lighting required for various windows types is shown in Fig. 11. From this figure it is seen that corner window needs more artificial lighting to fulfill the indoor lighting level. Therefore extra energy it costs extra energy cost per month is needed for any room which has corner window. On the other hand, it can be seen that artificial 
lighting level is less for horizontal window pattern than any other pattern. Therefore, its maintenance cost is less and require less electricity.

Approximate energy consumption per month for six types of window pattern is shown in Fig. 12.

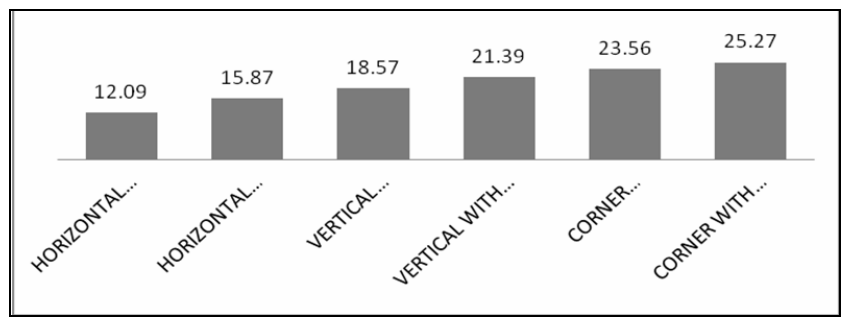

Fig. 12 Energy consumption per month of six type of window patterns.

From this figure it is seen that energy consumption is high (25.27 KWH) for the corner window with shading device and it goes gradually to the lower level. Energy consumption level per month is less for horizontal windows pattern. This analysis is generated from field survey and other case studies (S. W. A., Cannon-Brookes, 1997) and (A. Nabil and J Mardaljevic, 2005).

\section{CONCLUSION}

The result obtained in this study it is seen that the horizontal window provides significantly more light in the room than the vertical and corner windows at all times under sunny conditions. Under particular conditions, the vertical window results in higher illuminances than the horizontal window because of its geometry with respect to the sun and the way the direct sunlight patch reflects from the inner surfaces of the room. Negative result for horizontal window concerns the extremely large size and intensity of direct sunlight patches during summer, which means that shading device would be acute during this period. However, it is worth noting that the roof window also results in smaller direct sunlight patches during winter than the vertical window. Therefore, it could be mentioned that, shading device is preferable during the summer (to cut overheating) than during the winter when free solar heat gains and sunshine welcomes in the house. From this study it is also obtained that the corner window generally created a "tunnel" effect, yield a more concentrated light beam and lower light levels in the room, with darker, gloomier interior surfaces (walls).

\section{REFERENCES}

[1] Marsh, A., Eco-Tect, (2010), Conceptual design analysis tool, San Rafael, USA. Web link: www.autodesk.com/ecotect-analysis

[2] Power Development Authority, (2009-2010), Annual Report, Dhaka, Bangladesh

[3] S. W. A., Cannon-Brookes, (1997) Simple scale models for day lighting design: Analysis of sources of error in luminance prediction. Lighting Research and Technology, 29(3): pp 135-142.

[4] A. Nabil and J Mardaljevic. (2005) Useful daylight luminance: a new paradigm for assessing daylight in buildings. Lighting Research and Technology, 37(1): pp 41 to 57. 